\title{
Research on Cultural Content in Chinese College English Textbooks- A Case Study of New Standard College English Integrated Course 3
}

\author{
Guoping An*
}

Foreign Language Institute of North China Electric Power University, Baoding, Hebei, China

DOI: $10.36348 /$ sijll.2019.v02i10.004

| Received: 19.12.2019 | Accepted: 26.12.2019 | Published: 30.12.2019

*Corresponding author: Guoping An

\section{Abstract}

Language teaching is inseparable from culture teaching. As one of the basic elements of classroom teaching, this paper analyzes the cultural content of the New Standard College English Integrated Course 3 with the quantitative discussion. The results show that this course is still dominated by British and American culture, and the proportion of Chinese culture and other cultures is limited. The results of the analysis provide some references for publishing houses and Chinese English teaching.

Keywords: Cultural content, Chinese college English teaching; New Standard College English Integrated Course 3; Teaching model.

Copyright @ 2019: This is an open-access article distributed under the terms of the Creative Commons Attribution license which permits unrestricted use, distribution, and reproduction in any medium for non-commercial use (NonCommercial, or CC-BY-NC) provided the original author and source are credited.

\section{INTRODUCTION}

As one of the basic elements of classroom teaching, teaching material plays an indispensable role in teaching. It is the concrete embodiment of curriculum objectives and contents, as well as the main tool for teachers and students to carry out teaching activities. More importantly, it is not only a part of classroom teaching implementation, but also the carrier to achieve curriculum requirements and educational ideas. Similarly, as a basic element of English teaching, materials play an essential role in English teaching. The College English Teaching Guide published in 2017 clearly points out: college English curriculum is a part of humanistic education in colleges and universities, which has both instrumental and humanistic properties.

The core of humanity is human-oriented, carrying forward people's value, and paying attention to the cultivation and development of people's comprehensive quality. In addition, by learning and using English, students can understand the advanced scientific and technological development, and the world's excellent culture and civilization. At the same time, it can also help to enhance the national language strength, spread Chinese culture, and promote extensive exchanges with people of all countries. By learning the various cultures, students can deal with things in a more open attitude, communicate with people from different countries, and improve their understanding of national culture through comparison. This is actually the new trend and concept that foreign language teaching focuses on, that is, the awareness of cultural diversity and tolerance of differences, and the empathy of members of different cultures as well as awareness and reflection on their own cultural values and behavior [1]. In order to achieve these goals, English teaching materials should have an access to determine different types of cultural content and present its diversity and objectivity.

It is an indisputable fact that language teaching cannot be separated from culture teaching. Therefore, the customs, ways of behavior, thinking mode and values of the English nation must run through the whole process of English teaching. In the past half century, with the pace of globalization, English has become the most influential language.

Qi Yucun [2] believes that culture consists of three aspects: material culture (embodied in various physical products, such as tools, clothing, food, etc.), institutional custom culture (social norms and codes of conduct that people abide, including systems and corresponding facilities and customs, etc.) and spiritual culture (presented through people's way of thinking) It includes not only values, ways of thinking, aesthetic taste, moral sentiment, religious belief, but also achievements and products in philosophy, science, literature and art. Zhao Xianzhou, Zhang Zhanyi [3] and other scholars, from the theory of cross-cultural 
communication, think that culture includes knowledge culture and communicative culture. "Knowledge culture" refers to the linguistic and non linguistic cultural factors that do not directly affect the accurate transmission of information when two people with different cultural backgrounds communicate. The socalled communicative culture refers to the linguistic and non-verbal cultural factors that directly affect the accurate transmission of information (i.e. causing deviation or misunderstanding) when two people with different cultural backgrounds communicate.

\section{Analysis of the characteristics in New Standard College English Integrated Course 3}

The New Standard College English series, jointly completed by Simon Greenall, Wen Qiufang and other English education experts at home and abroad, are divided into four levels with eight units at each level.
Each unit contains two texts and one cultural reading. In the course introduction, it is written that the course has four characteristics: "rich content", "multi-task", "diversified culture" and "multi-model". It follows the concept of "people-oriented". The language materials are vivid and authentic, and it adapts to the teaching requirements of College English course, and meets the teaching needs in the new situation. Is that the case? With doubts, the author makes an in-depth analysis and evaluation of the cultural content in New Standard College English Integrated Course 3, which is open to freshmen in the first semester of North China Electric Power University, in order to find out whether there is an imbalance between the target language culture and the native culture in the cultural content setting. Based on this purpose, the author made the following three tables.

Table-1: The Cultural Contents in New Standard College English Integrated Course 3

\begin{tabular}{|c|c|c|c|}
\hline Unit and Theme & Specific Articles & Main Idea & $\begin{array}{l}\text { Cultural } \\
\text { territory } \\
\text { involved }\end{array}$ \\
\hline \multirow[t]{2}{*}{$\begin{array}{l}\text { Unit1 Discover } \\
\text { yourself }\end{array}$} & AR1: Catching crabs & $\begin{array}{l}\text { How a father gives advice to his son about } \\
\text { the future }\end{array}$ & U.S.A. \\
\hline & AR2: We are all dying & Advice on how to live in the moment & UK\&U.S.A. \\
\hline \multirow{2}{*}{$\begin{array}{l}\text { Unit2 Childhood } \\
\text { memories }\end{array}$} & AR1: The Glass Castle & A star-struck child's Christmas present & U.S.A \\
\hline & AR2: Cultural childhoods & $\begin{array}{l}\text { How the culture we grow up in creates the } \\
\text { experience of childhood }\end{array}$ & $\begin{array}{l}\text { UK\&U.S.A.\& } \\
\text { Africa }\end{array}$ \\
\hline \multirow[t]{2}{*}{$\begin{array}{l}\text { Unit3 Art for art's } \\
\text { sake }\end{array}$} & AR1: How we listen & $\begin{array}{l}\text { The fascinating insights of one of America's } \\
\text { great modern composers }\end{array}$ & U.S.A. \\
\hline & AR2: The photo & The enduring appeal of a split-second photo & U.S.A \\
\hline \multirow{2}{*}{$\begin{array}{l}\text { Unit4 No place like } \\
\text { home }\end{array}$} & AR1: Golden memories & A story about a house full of memories & UK\&U.S.A. \\
\hline & AR2: No place like home? & An illness or natural occurrence & U.S.A. \\
\hline \multirow{2}{*}{$\begin{array}{l}\text { Unit5 A place in } \\
\text { society }\end{array}$} & AR1: Dinner at Joanne's & A story of modern manners in New York & U.S.A. \\
\hline & AR2: I, we,they & $\begin{array}{l}\text { How do we learn about our place in our } \\
\text { society and which group we fit into }\end{array}$ & UK\&U.S.A. \\
\hline \multirow[t]{2}{*}{$\begin{array}{l}\text { Unit6 High days } \\
\text { and holidays }\end{array}$} & $\begin{array}{l}\text { AR1: Christmas Day in the } \\
\text { morning }\end{array}$ & The meaning of the Christmas Story & U.S.A. \\
\hline & $\begin{array}{l}\text { AR2: Chinese or Western, } \\
\text { it's time to relax }\end{array}$ & $\begin{array}{l}\text { Why we should enjoy Western as well as } \\
\text { Chinese festivals }\end{array}$ & U.S.A\&China \\
\hline \multirow[t]{2}{*}{$\begin{array}{l}\text { Unit7 Streets full } \\
\text { of heroes }\end{array}$} & $\begin{array}{l}\text { AR1: Last man down:the } \\
\text { fireman's story }\end{array}$ & A fireman's dramatic account of 9/11 & U.S.A \\
\hline & $\begin{array}{l}\text { AR2: Eleanor } \\
\text { Roosevelt:First lady of the } \\
\text { world }\end{array}$ & $\begin{array}{l}\text { The selfless achievements of Eleanor } \\
\text { Roosevelt }\end{array}$ & U.S.A \\
\hline \multirow[t]{2}{*}{$\begin{array}{l}\text { Unit8 Tales ancient } \\
\text { and modern }\end{array}$} & $\begin{array}{l}\text { AR1: Urban myths or urban } \\
\text { legends? }\end{array}$ & Myths,legends or hoaxes & UK \\
\hline & AR2: Echo and Narcissus & $\begin{array}{l}\text { A boy fell in love with his own reflection in } \\
\text { Greek myth }\end{array}$ & $\begin{array}{l}\text { Ancient } \\
\text { Greece }\end{array}$ \\
\hline
\end{tabular}


Table-2: The Translation Exercise in New Standard College English Integrated Course 3

\begin{tabular}{|l|l|l|}
\hline Unit and Theme & Translation Exercise & $\begin{array}{l}\text { Cultural territory } \\
\text { involved }\end{array}$ \\
\hline \multirow{2}{*}{ Unit1 Discover yoursel } & The change of majors among American College Graduates & U.S.A \\
\cline { 2 - 3 } & The understanding of Laozi's viewpoint of "knowing oneself" & UK\&U.S.A. \\
\hline \multirow{4}{*}{ Unit2 Childhood memorie } & $\begin{array}{l}\text { Western parents pay attention to the cultivation of their children's } \\
\text { independence }\end{array}$ & UK\&U.S.A. \\
\cline { 2 - 3 } & The advantages and disadvantages of children's rich material life & Global \\
\hline \multirow{5}{*}{ Unit3 Art for art's sake } & $\begin{array}{l}\text { Introduction to the famous painting "Guernica" by Spanish } \\
\text { painter Picasso }\end{array}$ & Spain \\
\cline { 2 - 3 } & $\begin{array}{l}\text { An introduction to the mural "flying apsaras" in Mogao Grottoes } \\
\text { of Dunhuang }\end{array}$ & China \\
\hline \multirow{2}{*}{$\begin{array}{l}\text { Unit4 No place like home } \\
\text { Unit5 A place in society }\end{array}$} & Changes in family structure in Europe & Europe \\
\cline { 2 - 3 } & On the aging problem in China & China \\
\cline { 2 - 3 } & Shat is the American dream & U.S.A \\
\hline \multirow{2}{*}{$\begin{array}{l}\text { Unit6 High days and } \\
\text { holidays }\end{array}$} & The origin of Mother's Day & Global \\
\cline { 2 - 3 } $\begin{array}{l}\text { Unit7 Streets full of } \\
\text { heroes }\end{array}$ & Introduction to Spring Festival & U.S.A.A \& Australia \\
\hline $\begin{array}{l}\text { Unit8 Tales ancient and } \\
\text { modern }\end{array}$ & Therican recognition to Heroes & U.S.A \\
\cline { 2 - 3 } & Introduction to Greek mythology & China \\
\cline { 2 - 3 } & $\begin{array}{l}\text { A comparison between ancient Greek mythology and Chinese } \\
\text { Mythology }\end{array}$ & Greece \&China \\
\hline
\end{tabular}

Table-3: Frequency of Territory in Reading across Culture of New Standard College English Integrated Course 3

\begin{tabular}{|c|c|c|c|c|}
\hline \multirow[t]{2}{*}{ Unit } & \multicolumn{2}{|c|}{ Western Countries } & \multirow{2}{*}{$\begin{array}{l}\text { Asian } \\
\text { Countries }\end{array}$} & \multirow[t]{2}{*}{ African Countries } \\
\hline & Native English & Non-Native English & & \\
\hline Unit 1 Rites of Passage & $\begin{array}{l}\text { U.S.A\& } \\
\text { Australia }\end{array}$ & & & \\
\hline $\begin{array}{l}\text { Unit } 2 \text { Childhood around the } \\
\text { world }\end{array}$ & UK\&U.S.A. & & $\begin{array}{l}\text { Korea } \\
\& \text { Russia }\end{array}$ & \\
\hline $\begin{array}{l}\text { Unit } 3 \text { The Top Five Paintings } \\
\text { in Western art }\end{array}$ & & France\&Spain\&Norway & & \\
\hline Unit 4 A roof over your head & UK & & & Africa \\
\hline Unit 5 Destination Europe & & Italy & & \\
\hline Unit 6 Day of the Dead & & Mexico & & \\
\hline $\begin{array}{l}\text { Unit } 7 \text { Heroes in Western } \\
\text { Literature }\end{array}$ & UK\&U.S.A & & & \\
\hline $\begin{array}{l}\text { Unit } 8 \text { Crow brings the } \\
\text { daylight:a story from the far } \\
\text { north }\end{array}$ & & Eskimo & & \\
\hline
\end{tabular}

\section{RESEARCH RESULTS AND DISCUSSION}

According to Table-1, the proportion of American culture is $87.5 \%$; British culture is $56.2 \%$; African culture, Chinese culture and ancient Greek culture is only $6.3 \%$. The so-called "multi culture" course introduction does not conform to the facts. It is obvious to notice the inadequate input of Chinese culture and other cultures.

Table-2 is the translation exercise of each unit, with $43.8 \%$ of the subjects involving in the national conditions and culture of the United Kingdom and the United States, $31.3 \%$ of the subjects involving the national conditions and culture of China, and only $6.3 \%$ of the subjects involving in the culture of Greece and Spain. Although Chinese culture is rarely mentioned in the main reading materials, it is worth advocating that the editor has designed many cultural comparison exercises involving China to strengthen the cultural sensitivity and cultural awareness of students, which is conducive to the cultivation of students' cross-cultural communication ability.

Table-3 shows the frequency of each territory in the thematic cultural reading, with $50 \%$ of British and American cultures, $62.5 \%$ of native non-English cultures, and only $12.5 \%$ of Asian and African cultures. It is noted that the 8 units cultural reading in textbook 3 fully reflects the cultural diversity, covering cultural life, traditional customs and values of more than ten countries. However, there are four times mentioning Britain and the United States (still higher than other countries), five times for the West, one time for Africa, and China is not mentioned. 


\section{Strategies for Teaching Cultural Content}

Based on the above analysis, it is pointed out that target culture serves neither the only content of foreign language learning, nor the ultimate goal of intercultural communication. English teaching concept should be corrected in time.

First of all, teachers should start from the teaching materials to inform and cultivate students' awareness of cultural diversity in explicit and implicit ways. It is worth praising that textbook 3 contains a small amount of introduction of non-British \& American culture and Chinese culture, which has made great progress compared with the previous published textbooks, and it changed the dominant role of British and American culture, and the dilemma of the longterm lack of native culture. This not only enables students to realize that native culture and target language culture have a place in English learning, but also enables them to have a deeper understanding of the two cultures only after making a comparison between Chinese and foreign cultures, helping students to become "productive learners", so that the improvement of their target language and native language level complement the appreciation of the two cultures so that learners' potential can be brought into full play [4].

However, if teachers intend to improve the intercultural communication ability of English learners, the teaching materials should create more opportunities for English learners to learn the target language culture, so that they can use English to talk about and learn Chinese and world culture, and also the teachers need to choose articles that can improve the cultural sensitivity and cultural awareness of students to achieve the teaching goal of College English.

Teachers should fulfill their subjective initiative. How to conduct the teaching design should be attached to priority. Take few units in New Standard College English (Book Three) for example.

In Unit 1 We Are All Dying, teachers can guide students to think about: "What are the differences between Chinese and Western attitudes towards death?" Chinese people are very taboo to say death, thinking death is not auspicious. In Chinese funeral, many places still follow the custom: the louder you cry, the more grief and respect you show to the dead. Westerners, especially Christians, believe that people can enter heaven after death. The funerals of western style are usually quiet. The family members of the dead invite their friends to memorize the dead through sharing their life story.

In Unit 3 Art for Art's Sake, teacher can design the following questions after learning The Top Five Paintings in Western World: 1. What are four essential elements used in the creation of Chinese Painting? 2. What is possibly the best known theme in Chinese paintings? 3. What are these painters trying to express?4. What can you infer about the differences between Chinese painting and western painting? Through discussion, students can get deeper insight into the art world.

In Unit 2 Cultural Childhood, the theme is "children in different cultures are different". The whole class can be divided into seven groups to claim tasks: children in American colonies, Inuit, Tonga, Beng, Western world, Fulani and Yanomamo. The key points for the group presentation include: a brief introduction of the country where the children belong; the characteristics of the children combined with the parents' responsibilities and expectations for the child; why adults treat children in different ways. After class, students can search the characteristics of children in other countries, such as Japan and India, and make comparison.

In Unit 4 No Place like Home, teachers can lead students to compare the different concepts towards home between Chinese and westerners. Chinese are more attached to home compared with westerners. Chinese are inclined to own a house rather than renting a house because house symbolizes success and stability. While westerners prefer to rent a house since they change jobs frequently.

In Unit 6 High Days and Holidays, students can find out the similarities and differences by comparing Spring Festival and Christmas. The similarities lie in the unity of family member, friends and relatives. The differences cover the forms and origin of the religion. Then the whole class can be divided into several groups: Christmas vs. Spring Festival; Halloween vs. Ghost day; Valentine's Day vs. Chinese Valentine's day. Each group can introduce the differences and similarities of the two festivals from the origin, meaning and ways of celebrating.

In Unit 8 Tales Ancient and Modern, students feel quite interested about the Greek Mythology. Teachers can take advantage of this opportunity to encourage students to find some Chinese tales. Through comparison, students can dig out the deeper reasons for these differences so that they can deepen the understanding of the diversity of culture.

\section{CONCLUSION AND ENLIGHTENMENT}

Since the 1980s, target culture has been the main content of English Teaching in China. The cultural points in textbook 3 take the British and American culture as the mainstream, which shows that the editor is deeply aware of the importance of the target language culture in English teaching.

With the continuous progress and rapid development of modern society, the compilation of teaching materials also encountered many 
unprecedented difficulties. Due to the development of science and technology and the popularization of computers, the ways and methods for students to contact the external culture are unprecedented, including various kinds of online social tools (such as Facebook, youtube, wechat, etc.), online self-Media (such as blog, microblog, etc.), computer games, chat rooms, etc. In the face of "well-informed" students, it is a great challenge for textbook writers to choose interesting and enlightening cultural materials. In order to solve this problem, the editor may listen to the opinions of teachers and students in many aspects, and may consider properly integrating the experiences and opinions of teachers, students and even foreign teachers into the teaching materials, which will not only facilitate teachers' teaching and attract students to learn, but also help improve students' cultural understanding and intercultural communication ability.

\section{ACKNOWLEDGEMENT}

This research is financially supported by Project of Promotion and Demonstration Plan for Excellent Teachers in North China Electric Power University (Baoding) (Grant NO. 13001904).

\section{REFERENCES}

1. Gao, Y. (2010). The cultivation of intercultural communication ability: crossing and crossing. Foreign language and foreign language teaching, (10):27-31.

2. Yucun, S. (1994). Three-year follow-up study of age-related dementia in an older population of Beijing urban area. Chinese Mental Health Journal, (4),4.

3. Zhang, Z. (1994). Communicative Culture and Knowledge Culture. Culture and Communication, Foreign Language Teaching and Researching Press, Beijing.

4. Yuan, F. (2006). An analysis of the position and role of mother tongue culture in foreign language teaching. Foreign language teaching, (5):67-70. 